\title{
Blood profiles and health in Holstein cows fed diets with varying cation-anion difference and calcium supplementation ${ }^{1}$
}

\author{
W.X. Wu ${ }^{1,2}$, Y.M. Wu ${ }^{1}$ and J.X. Liu ${ }^{1,3}$ \\ ${ }^{1}$ Institute of Dairy Science, MOE Key Laboratory of Molecular Animal Nutrition, \\ Zhejiang University \\ Hangzhou 310029, P.R. China \\ ${ }^{2}$ College of Animal Science, Guizhou University \\ Guiyang 550025, P.R. China
}

\begin{abstract}
Three blocks each of twelve Holstein cows beginning 21 days prepartum were randomly allocated to one of three treatments with varying dietary cation-anion difference (DCAD, $\mathrm{mEq} / \mathrm{kgDM})$ at +150 (HD), -100 (LD), and -100 plus calcium (LDCA) to investigate fluid acid-base balance, serum $\mathrm{Ca}$, health status, and lactation performance. Feeding LD diets induced mild metabolic acidosis. Serum $\mathrm{Ca}$ in diet $\mathrm{LD}$ was higher $(\mathrm{P}<0.05)$ than that in other two diets. Health disorder was lower in the two LD diets. Milk yield was unaffected $(\mathrm{P}<0.05)$ by dietary treatments. It is indicated that negative DCAD was beneficial for blood calcium homeostasis and health status in Holstein periparturient cows.
\end{abstract}

KEY WORDS: dietary cation-anion, calcium, health, Holstein cows

\section{INTRODUCTION}

Improvement of blood calcium $(\mathrm{Ca})$ homeostasis by lowering dietary cationanion difference (DCAD) in the prepartum diet has been drawing increasing attention over the past years (Moore et al., 2000; Lean et al., 2006), which is achieved by inclusion of anionic salts into diet. The lowering DCAD can reduce milk fever through enhancing $\mathrm{Ca}$ absorption and bone $\mathrm{Ca}$ resorption.

In our previous trial (Wu et al., unpublished) it was observed that the critical days around calving was the most significant phase, responsible for greater blood $\mathrm{Ca}$ homeostasis in cows fed reduced DCAD. Following that, this study was

\footnotetext{
${ }^{*}$ Supported by grants from Ministry of Science and Technology of China and Zhejiang Provincial Department of Science and Technology, China

${ }^{3}$ Corresponding author: e-mail: liujx@zju.edu.cn
} 
conducted to investigate the fluid acid-base balance, serum mineral concentrations, health status, and subsequent lactation performance in Holstein periparturient cows fed diets with low CAD and Ca supplementation.

\section{MATERIAL AND METHODS}

\section{Experimental design}

Thirty-six pregnant Holstein multiparous dry cows beginning 21 days prepartum were assigned to three blocks each of twelve cows based on their age and previous $305-d$ equivalent milk yield using randomized block design. The cows were randomly allocated to one of three treatments with varying DCAD $(\mathrm{Na}+\mathrm{K}-\mathrm{Cl}-\mathrm{S}, \mathrm{mEq} / \mathrm{kg}$ $\mathrm{DM})$ at +150 (HD), -100 (LD), and -100 plus $\mathrm{Ca}$ (LDCA). Anionic salts were used to decrease $\mathrm{DCAD}$, and bicalcium phosphate was added to increase dietary Ca content. The supplementary Ca was $30 \mathrm{~g} /$ day in diet LDCA. Cows were fed total mixed rations ad libitum, milked three times daily and had free access to drinking water throughout this experiment. Ingredients and nutritive level of the diet are shown in Table 1.

Table 1 . The ingredients and nutritive level of dry cow diet, $\% \mathrm{DM}$

\begin{tabular}{|c|c|c|c|}
\hline \multirow{2}{*}{ Item } & \multicolumn{3}{|c|}{ Treatment $^{1}$} \\
\hline & HD & LD & LDCA \\
\hline \multicolumn{4}{|l|}{ Ingredient } \\
\hline maize silage & 25.4 & 24.5 & 24.3 \\
\hline Chinese wild rye-grass & 13.5 & 13.1 & 13.0 \\
\hline lucerne hay & 22.8 & 22.0 & 21.9 \\
\hline sweat potato & 10.2 & 9.8 & 9.7 \\
\hline concentrate mixture $^{2}$ & 28.1 & 27.1 & 25.9 \\
\hline bicalcium phosphate & & & 1.8 \\
\hline anionic salts ${ }^{3}$ & & 3.5 & 3.5 \\
\hline \multicolumn{4}{|l|}{ Nutrient concentration } \\
\hline $\mathrm{CP}$ & 12.9 & 13.7 & 13.7 \\
\hline NDF & 40.5 & 39.8 & 39.8 \\
\hline $\mathrm{ADF}$ & 23.6 & 23.0 & 23.0 \\
\hline $\mathrm{Ca}$ & 0.85 & 0.82 & 1.05 \\
\hline $\mathrm{P}$ & 0.37 & 0.38 & 0.38 \\
\hline $\mathrm{Na}$ & 0.371 & 0.365 & 0.365 \\
\hline $\mathrm{K}$ & 1.263 & 1.241 & 1.241 \\
\hline $\mathrm{Cl}$ & 0.685 & 1.146 & 1.146 \\
\hline $\mathrm{S}$ & 0.171 & 0.354 & 0.354 \\
\hline $\mathrm{DCAD}^{4}$ & +185 & -67 & -67 \\
\hline Ca intake, $\mathrm{g} / \mathrm{d}$ & 100 & 100 & 130 \\
\hline
\end{tabular}

${ }^{1} \mathrm{HD}$ - high DCAD; LD - low DCAD; LDCA - low DCAD plus Ca; ${ }^{2}$ ingredient, \%: maize 40, barley 29 , wheat bran 10 , cottonseed meal 10 , rapeseed meal 5 , bicalcium phosphate 3.5 , salt 1 , premix 1.5; ${ }^{3}$ ingredient: $\mathrm{NH}_{4} \mathrm{Cl}, \mathrm{CaCl}_{2}, \mathrm{MgSO}_{4}, \mathrm{CaSO}_{4}$, molasses, DDGS, etc.; composition, \%: CP 35.7 , NDF 19.9, ADF 6.6, Ca 1.10, P 0.55, Mg 3.65, Na 0.17, K 0.53, S 4.65, Cl 11.90;

${ }^{4}$ actually determined dietary cation-anion difference, $\mathrm{mEq} / \mathrm{kg} \mathrm{DM}$ 


\section{Samples and measurement}

The representative prepartum dietary samples were collected once a week and composited to analyse approximate chemical compositions. Contents of $\mathrm{Na}$ and $\mathrm{K}$ were measured using atomic absorption spectrophotometry (AA-6501, SHIMADZU, Japan), Cl was assessed by a potentiometer (DZ-1, Shanghai, China), and S was detected using magnesium nitrate method (Wang and Beede, 1991). Urinary samples were obtained for $\mathrm{pH}$ measurement. The blood was sampled from coccygeal vein to assess acid-base balance (Roche OMNIC, Swiss) and $\mathrm{Ca}, \mathrm{P}$, and $\mathrm{Mg}$ concentrations (Olympus-2700, Japan). Health status was recorded according to Goff and Horst (1997). Dry matter intake (DMI) prepartum was recorded once a week. Milk yields were detected on $\mathrm{d} 20$ and 21 postpartum and milk compositions on $\mathrm{d} 21$ postpartum using Milko-Scan (Foss-4000, Hillerød, Denmark).

\section{Statistical analysis}

The SAS software system was used to analyse data using GLM procedure. Health status was analysed by Chi-square test. The effects of dietary treatment, blood sampling time, and their interaction were included into the statistical model. The difference between treatments means were examined by Duncan's multiple range test. A statistical significance was declared when the $\mathrm{P}<0.05$.

\section{RESULTS}

Feeding diet HD induced higher $(\mathrm{P}<0.05)$ urinary and blood $\mathrm{pH}$ than the two LD diets, with little difference $(\mathrm{P}>0.05)$ between two LD diets (Table 2). No significant difference $(\mathrm{P}>0.05)$ was observed in blood $\mathrm{HCO}_{3}^{-}$concentration among three treatments. The marked declination of urinary $\mathrm{pH}$ was accompanied by the minor reductions in blood $\mathrm{pH}$ and $\mathrm{HCO}_{3}{ }^{-}$concentration.

Table 2. Fluid acid-base balance and serum mineral concentrations in dairy cows fed diets with varying cation-anion difference and calcium supplementation

\begin{tabular}{lcccc}
\hline \multirow{2}{*}{ Item } & \multicolumn{3}{c}{ Treatment $^{1}$} & \multirow{2}{*}{ SEM } \\
\cline { 2 - 4 } & $\mathrm{HD}$ & LD & LDCA & \\
\hline Urine $\mathrm{pH}$ & $7.99^{\mathrm{a}}$ & $6.25^{\mathrm{b}}$ & $6.17^{\mathrm{b}}$ & 0.082 \\
Blood $\mathrm{pH}$ & $7.42^{\mathrm{a}}$ & $7.37^{\mathrm{b}}$ & $7.37^{\mathrm{b}}$ & 0.006 \\
${\text { Blood } \mathrm{HCO}_{3}^{-}, \mathrm{mmol} / \mathrm{L}}^{21.0}$ & 20.7 & 19.9 & 0.740 \\
Serum minerals, mg/dL & & & & \\
$\mathrm{Ca}$ & & & & \\
$\mathrm{P}$ & $8.71^{\mathrm{b}}$ & $9.08^{\mathrm{a}}$ & $8.76^{\mathrm{b}}$ & 0.085 \\
$\mathrm{Mg}$ & $4.92^{\mathrm{b}}$ & $5.29^{\mathrm{a}}$ & $5.23^{\mathrm{ab}}$ & 0.123 \\
\hline
\end{tabular}

${ }^{1} \mathrm{HD}$ - high DCAD; LD - low DCAD; LDCA - low DCAD plus Ca

a,b means in the same row with different superscripts differ $(\mathrm{P}<0.05)$ 
Serum $\mathrm{Ca}$ in LD diet was higher $(\mathrm{P}<0.05)$ than that in diets HD and LDCA (Table 2). Diet LD resulted in higher serum $\mathrm{P}(\mathrm{P}<0.05)$ than diet HD. Feeding of diet LDCA induced higher serum $\mathrm{Mg}(\mathrm{P}<0.05)$ than diet $\mathrm{LD}$. The nadir of serum $\mathrm{Ca}$ was observed on $\mathrm{d} 0.5$ postpartum (Figure 1). Cows fed diet LD had higher serum $\mathrm{Ca}(\mathrm{P}<0.05)$ than those on diet HD on $\mathrm{d} 0.5$ and $\mathrm{d} 2$ postpartum. Diet LDCA resulted in higher serum $\mathrm{Mg}(\mathrm{P}<0.05)$ than diet $\mathrm{HD}$ on $\mathrm{d} 0.5$ postpartum and diet $\mathrm{LD}$ on $\mathrm{d} 2$ postpartum. Serum $\mathrm{Ca}, \mathrm{P}$ and $\mathrm{Mg}$ levels were unaffected $(\mathrm{P}>0.05)$ by the interaction of treatment and blood sampling time (data not shown).
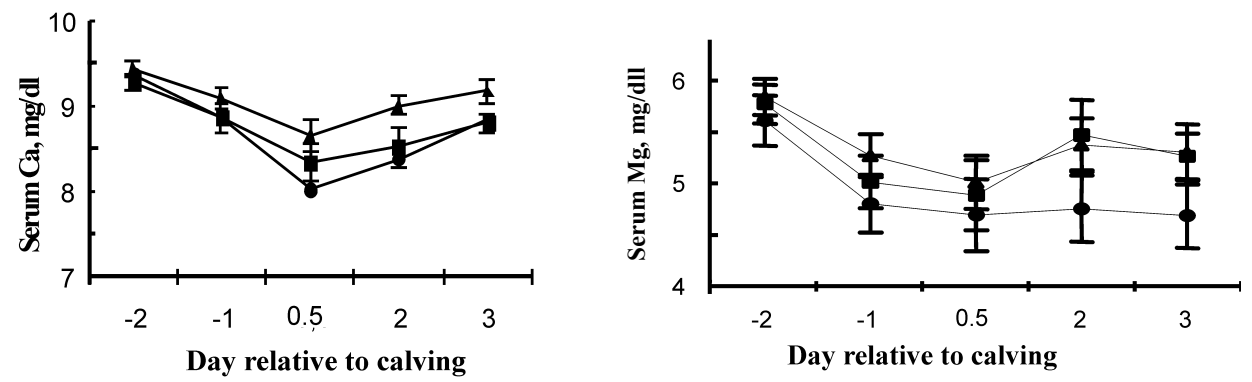

Figure 1. Change in serum calcium and magnesium concentrations in transition Holstein cows fed diets with high $(\bullet)$, low ( $\bullet$ ) cation-anion difference (LD), and LD with supplementation of calcium $(\diamond)$ Results are means \pm standard error

No milk fever and displaced abomasum occurred during the experiment (Table 3). Hypocalcaemia cases in diet HD was higher $(\mathrm{P}<0.05)$ than that in diet LD. Feeding diet LDCA resulted in lower $(\mathrm{P}<0.05)$ retained placenta incidence than diet HD. The occurrence of udder oedema in cows fed diet HD was $16.7 \%$ higher than for the two LD diets, respectively. The total cases of disorder were 14, 4, and 4 in diets HD, LD, and LDCA, respectively.

Table 3. Health status in dairy cows fed diets with varying cation-anion difference and calcium supplementation

\begin{tabular}{lccc}
\hline \multirow{2}{*}{ Item } & \multicolumn{3}{c}{ Treatment ${ }^{1}$} \\
\cline { 2 - 4 } & HD & LD & LDCA \\
\hline Milk fever & $0 / 12$ & $0 / 12$ & $0 / 12$ \\
Hypocalcaemia & $4 / 12^{\mathrm{a}}$ & $0 / 12^{\mathrm{b}}$ & $1 / 12^{\mathrm{ab}}$ \\
Retained placenta & $6 / 12^{\mathrm{a}}$ & $2 / 12^{\mathrm{ab}}$ & $1 / 12^{\mathrm{b}}$ \\
Udder oedema & $3 / 12$ & $1 / 12$ & $1 / 12$ \\
Displaced abomasums & $0 / 12$ & $0 / 12$ & $0 / 12$ \\
Mastitis & $1 / 12$ & $1 / 12$ & $1 / 12$ \\
No. of total disorder & 14 & 4 & 4 \\
\hline
\end{tabular}

${ }^{1} \mathrm{HD}$ - high DCAD; LD - low DCAD; LDCA - low DCAD plus Ca

a,b means within a row with different superscripts $(\mathrm{P}<0.05)$ 
Dietary treatments did not have significant influence $(\mathrm{P}>0.05)$ on DMI prepartum (Table 4). The milk yield, fat, and protein were not different $(\mathrm{P}>0.05)$ among treatments. Diet LDCA induced higher $(\mathrm{P}<0.05)$ lactose than diet HD.

Table 4. Lactation performance in dairy cows fed diets with varying cation-anion difference and calcium supplementation

\begin{tabular}{lcclc}
\hline \multirow{2}{*}{ Item } & \multicolumn{3}{c}{ Treatment $^{1}$} & \multirow{2}{*}{ SEM } \\
\cline { 2 - 4 } & HD & LD & LDCA & \\
\hline Prepartum DM intake, kg/d & 11.96 & 12.00 & 12.01 & 0.156 \\
Milk yield, kg/d & 31.4 & 31.3 & 32.4 & 1.683 \\
Composition, \% & & & & \\
fat & 4.69 & 4.46 & 4.08 & 0.299 \\
protein & 3.19 & 3.25 & 3.21 & 0.144 \\
lactose & $4.70^{\mathrm{b}}$ & $4.83^{\text {ab }}$ & $4.85^{\mathrm{a}}$ & 0.047 \\
\hline
\end{tabular}

${ }^{1} \mathrm{HD}$ - high DCAD; LD - low DCAD; LDCA - low DCAD plus Ca

${ }^{a, b}$ means within a row with different superscripts $(\mathrm{P}<0.05)$

\section{DISCUSSION}

The significantly lower urinary $\mathrm{pH}$ and limited decrease in blood $\mathrm{pH}$ and $\mathrm{HCO}_{3}^{-}$concentration for the two LD diets than $\mathrm{HD}$ diet indicates the achievement of mild metabolic acidosis (Goff and Horst, 1998; Moore et al., 2000). The Ca supplementation $(30 \mathrm{~g} / \mathrm{d})$ in this study is shown to be insufficient to change fluid acid-base balance by the non-significant difference in urinary and blood $\mathrm{pH}$, and blood $\mathrm{HCO}_{3}^{-}$concentration between the two LD diets.

Cows fed diet LD had higher serum $\mathrm{Ca}$ than those on diet HD displays that low DCAD diet may reduce the normal decline in serum $\mathrm{Ca}$ and aid in preventing hypocalcaemia (Table 3 ). Serum $\mathrm{Ca}$ is unexpectedly to be higher in cows receiving diet LD than those offered diet LDCA, though it was reported that reduced DCAD would result in higher blood $\mathrm{Ca}$ via the enhanced $\mathrm{Ca}$ absorption from intestine, higher parathyroid hormone $(\mathrm{PTH})$ and 1,25-(OH) $\mathrm{D}_{3}$ (Goff et al., 1991) and the increased bone resorption (Brandao-Burch et al., 2005). Chan et al. (2006) also observed that serum $\mathrm{Ca}$ did not show significant difference between the diets with high $(1.50 \%, 165$ $\mathrm{g} / \mathrm{d})$ and low $(0.99 \%, 109 \mathrm{~g} / \mathrm{d})$ dietary Ca contents in cows fed diet with -60 DCAD. An explanation could be that the supplementary $\mathrm{Ca}$ in diet LDCA blunts the activity of PTH and 1, 25-(OH $)_{2} \mathrm{D}_{3}$ inducing the inhibition of Ca turnover. Further larger-scale and longer-term trials are needed to confirm the results presented here.

No milk fever occurred because all cows never had their serum Ca levels below the critical value $5.5 \mathrm{mg} / \mathrm{dl}$ (Goffand Horst, 1997). The decreased hypocalcaemia incidence with the reduced DCAD is consistent with the literature (Lean et al., 2006) and may reflect that serum $\mathrm{Ca}$ in cows consuming the two LD diets was more stable than that in diet HD. Kimura et al. (2006) reported that Ca signal in the immune cells was blunted 
by hypocalcaemia and that the periparturient $\mathrm{Ca}$ stress preceded hypocalcaemia. Cows fed diet HD produced higher $(\mathrm{P}<0.05)$ retained placenta occurrence than those on diet LD. This may be because retained placenta was associated with hypocalcaemia (Goff and Horst, 1997), which could result in weak uterine contraction tone and immunosuppression in dairy cows at calving (Kimura et al., 2002). Overall, feeding negative DCAD diet can reduce periparturient cows' health disorders.

No difference was observed in DMI prepartum for three treatments, probably because the anionic salts used in this study was pelletized and mixed with molasses and distillers dried grains plus solubles, masking the unpalatability of untreated anionic salts. Milk yield, fat and protein were unaffected by dietary treatments. Diet LDCA induced limited higher lactose than diet HD.

\section{CONCLUSIONS}

Feeding of diet with low cation-anion difference (CAD) and Ca supplementation can change fluid acid-base balance and improve health status; but is not as adequate as negative dietary $\mathrm{CAD}$ for blood $\mathrm{Ca}$ homeostasis in periparturient Holstein dairy cows.

\section{REFERENCES}

Brandao-Burch A., Utting J.C., Orriss I.R., Arnett T.R., 2005. Acidosis inhibits bone formation by osteoblasts in vitro by preventing mineralization. Calcified Tissue Int. 77, 167-174

Chan P.S., West J.W., Bernard J.K., 2006. Effect of prepartum dietary calcium on intake and serum and urinary mineral concentrations of cows. J. Dairy Sci. 89, 704-713

Goff J.P., Horst R.L., 1997. Effects of the addition of potassium or sodium, but not calcium, to prepartum rations on milk fever in dairy cows. J. Dairy Sci. 80, 176-186

Goff J.P., Horst R.L., 1998. Use of hydrochloric acid as a source of anions for prevention of milk fever. J. Dairy Sci. 81, 2874-2880

Goff J.P., Horst R.L., Mueller F.J., Miller J.K., Kiess G.A., Dowlen H.H., 1991. Addition of chloride to a prepartal diet high in cations increases 1,25 -dihydroxyvitamin $\mathrm{D}$ response to hypocalcemia preventing milk fever. J. Dairy Sci. 74, 3863-3871

Kimura K., Goff J.P., Kehrli Jr. M.E., Reinhardt T.A., 2002. Decreased neutrophil function as a cause of retained placenta in dairy cattle. J. Dairy Sci. 85, 544-550

Kimura K., Reinhardt T.A., Goff J.P., 2006. Parturition and hypocalcemia blunts calcium signals in immune cells of dairy cattle. J. Dairy Sci. 89, 2588-2595

Lean I.J., DeGaris P.J., McNeil D.M., Block E., 2006. Hypocalcemia in dairy cows: meta-analysis and dietary cation-anion difference theory revisited. J. Dairy Sci. 89, 669-684

Moore S.J., Vandehaar M.J., Sharma B.K., Pilbeam T.E., Beede D.K., Bulcholtz H.F., Liesman J.S., Horst R.L., Goff J.P., 2000. Effects of altering dietary cation-anion difference on calcium and energy metabolism in peripartum cows. J. Dairy Sci. 83, 2095-2104

Wang C., Beede D.K., 1991. Effects of supplemental protein on acid-base status and calcium metabolism of nonlactating Jersey cows. J. Dairy Sci. 73, 3178-3186

Wu W.X., Liu J.X., Xu G.Z., Ye J.A., 2007. Calcium homeostasis, acid-base balance, and health status in periparturient Holstein cows fed diets with low cation-anion difference. Livest. Sci. (in press revision) 